DOI https://doi.org/10.30525/978-9934-26-073-5-2-31

\title{
ДО ПИТАННЯ ПРО ПЕРЕКЛАДОЗНАВЧЕ ТЛУМАЧЕННЯ ПОНЯТТЯ КУЛЬТУРИ
}

\author{
Ляшенко Т. С. \\ кандидат філологічних наук, \\ доцент кафедри міжкультурної комунікації та перекладу \\ Львівського національного університету імені Івана Франка \\ м. Львів, Украӥна
}

Починаючи з 80-х років минулого століття поняття культури стає одним з ключових в перекладознавстві. Науковці тлумачать переклад як міжкультурний процес [10], говорять про переклад як міжкультурне явище (cross-cultural event) [11], описують його як міжкультурний трансфер [12] та як свідомий обмін культурними цінностями між народами [2]. Попри беззаперечне визнання вагомості феномену культури для перекладу і широке його використання в перекладознавстві це поняття ще потребує диференційованого визначення, що зумовлює актуальність цієї розвідки.

Питання тлумачення поняття культури в німецькомовному просторі ставало предметом розгляду низки науковців. Зокрема, окреслено нові орієнтири в науках про культуру [6]; здійснено спробу з'ясувати значення поняття культури i культрології для перекладознавства i практики перекладу [5]; подано критичний огляд підходів до феномену культури, охарактеризовано найрепрезентативніші дефініції цього поняття в перекладознавчій літературі [8]; у межах транскультурної комунікації виокремлено два концептуальних підходи до поняття культури [7]. В українськомовних дослідженнях розглянуто питання взаємозв'язку та взаємодії культури та перекладу [2]; проаналізовано проблему місця і ролі поняття «культура» в теорії і практиці перекладу [4]; у межах культуроцентричного підходу розглянуто культуру як оперативну одиницю перекладу із вербальним втіленням [3], а також окреслено зв'язок перекладу із процесами націєтворення з опорою на методологію «культурного повороту» [1].

Методологічні зміни наприкінці 80 -х років $\mathrm{XX}$ ст. зумовили появу нових концепцій розуміння культури, плюралізм яких демонструє німецька літературознавиця i культурологиня Д. Бахманн-Медік у роботі «Культурні повороти. Нові орієнтири в науках про культуру». Дослідниця веде мову про 7 культурних поворотів у науках про 
культуру, кожен з яких має своє бачення цього поняття. Перспективним для перекладознавства вважаємо поєднання лінгвістичного, інтерпретативного i перекладацького поворотів. Головним постулатом лінгвістичного повороту є тісний зв'язок мови та культури. У межах інтерпретативного підходу до культури цей феномен тлумачать як цілісну системну організацію текстів із знаковою i символічною сутністю. Крізь метафору тексту культуру слід сприймати як ансамбль текстів, як систему смислів і значень у її багатошаровості прочитання, що в залежності від контексту призводить до множинних інтерпретацій культурних значень [6, с. 72]. Перекладацький поворот перетворює перекладознавство на культурологічне дослідження перекладу. Саме поняття перекладу тлумачать насамперед як культурний трансфер, а в цьому процесі водночас і трансфер мовний [10, с. 122]. Водночас відбувається і перекладацьке переосмислення культури, яку розуміють як процес перекладу - «культура як переклад». Перекладний характер культур вбачають у їх гібридності і багатошаровості, які є проявом i результатом активних перекладацьких процесів [6, с. 248].

3 огляду на сутність перекладу як міжкультурної комунікації вважаємо релевантними для перекладознавства визначення поняття культури в таких галузях наук, які передбачають застосування або теоретичне обгрунтування міжкультурного порівняння. Зокрема, перекладознавче визначення поняття культури, на нашу думку, мало би поєднувати головні аспекти його розуміння у культурології, соціальнокультурній антропології і міжкультурній комунікації.

Справедливою, на наш погляд, $\epsilon$ критика спроб абстрактного визначення поняття культури в теорії перекладу, оскільки такий підхід не дає змоги розпізнати прояви культури в тексті [8, с. 27-28]. У німецькомовному перекладознавстві, зокрема у функціональній теорії перекладу, провідною стає дефініція Г. Гьорінга. Розвиваючи ідеї американського антрополога В. Гудинафа, науковець пристосовує поняття культури до завдань перекладача і визначає іiі як «все те, що перекладач має знати і відчувати з огляду на суспільство вихідної мови та мови перекладу» (переклад - Т. Л.). Таке розуміння культури дає змогу перекладачеві оцінити прийнятність моделей поведінки й очікування суспільства, самому відповідно до них діяти і сприймати світ (і тексти) як її представник [9, с. 112].

У транскультурній комунікації важливо розрізняти щонайменше два виміри поняття культури: змістовний і екстенсіональний (просторовий). Зумовлене культурними поворотами критичне переосмислення поняття культури на змістовному рівні призвело до розширення цього поняття: 
до культури почали відносити також «мову i текст як формотвірні i рушійні сили соціальної дії» [6, с. 13]. Розширене тлумачення культури на рівні змістовному загрожує узагальненням і есенціалізацією його визначень, якщо не відбуватиметься переосмислення культури на рівні екстенсіональному [7, с. 233]. Визначення просторового виміру у перекладознавстві становить певні труднощі через його змінний характер (національний чи соціальний рівень). Для перекладознавчого визначення культури релевантною спільнотою, яку охоплює простір культурного середовища, вважаємо спільноту лінгвокультурну як єдність народу, його мови і культури.

Художній текст як віддзеркалення тексту культури $є$ своєрідним явищем. Його особливий світ можна віднести до певної культури, враховуючи очевидні посилання автора на певні культури за допомогою експліцитних засобів, або імпліцитні вказівки на дії, вчинки, специфічні риси, які зазвичай асоціюють з моделями певної культури. Культурну інформацію в художньому тексті можна поділити на дві групи: культура в мові (особливості культури, зафіксовані в мові) і культура, описувана мовою (представлені в змісті тексту об’єкти національної матеріальної і духовної культури як позамовної реальності).

Науково-методичні підходи до перекладу культури в текстах демонструють суперечність між поглядами, спрямованими на окремі елементи культури на рівні мікроструктурному, i прагненнями до цілісного розгляду культури в тексті на рівні макроструктурному [8, с. 50]. Доцільним вважаємо системний опис культури в художніх текстах, щоби уможливити іiі ідентифікацію на обох рівнях. Оскільки наявні методи перекладу елементів культури в текстах насамперед орієнтовані на фазу реалізації повідомлення мовою перекладу, пропонуємо розглядати питання ідентифікації та перекладу культурної інформації також на етапах декодування вихідного тексту та його перекодування.

Аналіз різних підходів до окреслення поняття культури і релевантних для перекладу аспектів його дослідження дозволив запропонувати таку перекладознавчу дефініцію: культура - це складна, ієрархічно організована система матеріальних, духовних i соціальних цінностей певної лінгвокультурної i/або соціокультурної спільноти, які виражають особливості їі світобачення, суспільного і повсякденного життя. Культура знаходить своє відображення в мові і тексті як особлива мовна картина світу й об'єкт опису та продовжує своє існування в діалозі 3 іншими культурами, можливому завдяки перекладу як культурологічному явищу i перекладачеві як експерту з прочитання складної системи смислів і значень вихідної культури і культури перекладу. 
Запропоноване перекладознавче визначення поняття культури, на нашу думку, дає змогу окреслити культурні фонові знання перекладача, необхідні з одного боку для розуміння тексту, а з іншого для адекватного перекладу культурної інформації. Здатність виявити культурну інформацію в тексті вважаємо важливою передумовою здійснення адекватного перекладу.

\section{Література:}

1. Альошина М. Методологія «культурного повороту» в сучасному перекладознавстві і проблеми адекватності в перекладі. Фаховий та художній переклад: теорія, методологія, практика: збірник наукових праць. 2014. С. 17-21.

2. Зорівчак Р. Український художній переклад як націєтворчий чинник. Зарубіжна література. 2007. № 14. С. 1-5.

3. Кузенко Г. М. Культурологічний аспект перекладу у міжмовній комунікації. Міжнародний науковий журнал «Інтернаука». 2017. № 2(2). C. 22-26. URL: http://nbuv.gov.ua/UJRN/mnj_2017_2(2)_6 (дата звернення: 16.04.2021)

4. Олійник Т. С. Поняття «культура» у сучасному перекладознавстві. Наукові записки Начіонального університету «Острозька академія». Серія: Філологічна. 2014. Вип. 45. С. 292-295. URL: http://nbuv.gov.ua/ UJRN/Nznuoaf_2014_45_87 (дата звернення: 16.04.2021).

5. Albrecht J. „Kultur» und Kulturwissenschaft. Ihre Bedeutung für die Translationswissenschaft und für die Translationspraxis.» In: Lavinia Heller, ed. Kultur und Übersetzung. Studien zu einem begrifflichen Verhältnis. Bielefeld, 2017. S. 65-91.

6. Bachmann-Medick D. Cultural Turns: Neuorientierungen in den Kulturwissenschaften. Reinbek bei Hamburg, 2009. 419 S.

7. Dengscherz S. Kampf der Kulturbegriffe? Eine Fallstudie zum wissenschaftlichen Schreiben über „Kultur» im BA-Studium „Transkulturelle Kommunikation». HERMES - Journal of Language and Communication in Business. 2018. Vol. 58. S. 231-256. DOI: https://doi.org/10.7146/ hjlcb.v0i58.111688

8. Floros G. Kulturelle Konstellationen in Texten. Zur Beschreibung und Übersetzung von Kultur in Texten. Tübingen, 2003. 234 S.

9. Göhring H. „Interkulturelle Kommunikation». In: Snell-Hornby et al., eds. Handbuch Translation. 2. Aufl. Tübingen, 2006. S. 112-115.

10. Reiß K., Vermeer H. J. Grundlegung einer allgemeinen Translationstheorie. Linguistische Arbeiten, 147. Tübingen, 1984. 
11. Snell-Hornby M. Translation Studies. An integrated approach. Amsterdam [u.a.], 1988. 170 p.

12. Vermeer H. J. „Übersetzen als kultureller Transfer». In: Snell-Hornby M., ed. Übersetzungswissenschaft: Eine Neuorientierung. Tübingen, 1986. S. 30-53.

DOI https://doi.org/10.30525/978-9934-26-073-5-2-32

\title{
МАКСИМ РИЛЬСЬКИЙ - ІНТЕРПРЕТАТОР ТВОРЧОСТІ АДАМА МЩКЕВИЧА
}

\author{
Маркуляк Л. В. \\ кандидат філологічних наук, \\ доиент кафедри української літератури \\ Чернівецького начіонального університету \\ імені Юрія Федьковича \\ м. Чернівиі, Украӥна
}

Максим Рильський - визначний український поет, перекладач, літературознавець, культурно-громадський діяч, справжній «архимайстер слова» (Свген Маланюк).

Переклад посідає вагоме місце у творчому доробку українського поета. Розпочавши свою перекладацьку діяльність у 20-і pp. XX ст., М. Рильський усвідомлював значення цього виду творчості для української культури. Поет не міг уповні розкритися як самобутній автор у власній поезії, позаяк після арешту 1931 року відбувся злам у його свідомості. Його літературні побратими, серед яких і «п'ятірне гроно»неокласики, зазнавали переслідувань, репресій аж до фізичного знищення. Радянська тоталітарна система «подбала», аби талановитий поет, який миттєво піднявся на український Парнас, оприявнивши власне обличчя, опинився після «зламу» у внутрішній еміграції. Рятівним виявився для нього саме переклад, адже без літературної творчості М. Рильський не міг себе уявляти. У перекладі поет розкрився в новому амплуа, зарепрезентувавши вміння тонкого і вправного Майстра.

У радянський час М. Рильський здійснює переклади творів 3 польської, російської, французької та ін. літератур, компенсуючи прогалини у власній творчості, яку в цей час довелося «приспати». Тому втечу у переклад, як мені видається, можна пояснити, з одного боку, неможливістю написати незаангажовані твори через вимушене 